NBER WORKING PAPER SERIES

\title{
INTERNATIONAL STUDENT MOBILITY: GROWTH AND DISPERSION
}

\author{
Neeraj Kaushal \\ Mauro Lanati \\ Working Paper 25921 \\ http://www.nber.org/papers/w25921
NATIONAL BUREAU OF ECONOMIC RESEARCH
1050 Massachusetts Avenue
Cambridge, MA 02138
June 2019

The authors are grateful to C. Simon Fan, Ettore Recchi and Martin Ruhs for their extremely helpful comments and suggestions. Mauro Lanati thanks Stiftung Mercator for financial support under project number PN 14-297. The views expressed herein are those of the authors and do not necessarily reflect the views of the National Bureau of Economic Research.

NBER working papers are circulated for discussion and comment purposes. They have not been peer-reviewed or been subject to the review by the NBER Board of Directors that accompanies official NBER publications.

(C) 2019 by Neeraj Kaushal and Mauro Lanati. All rights reserved. Short sections of text, not to exceed two paragraphs, may be quoted without explicit permission provided that full credit, including $(\odot$ notice, is given to the source. 
International Student Mobility: Growth and Dispersion

Neeraj Kaushal and Mauro Lanati

NBER Working Paper No. 25921

June 2019

JEL No. J1,J15,J24

\begin{abstract}
$\underline{\text { ABSTRACT }}$
Recent years have seen an unprecedented growth and geographic dispersion in international student mobility. In this paper, we empirically test the predictions of two competing theoretical models underpinning the determinants of student mobility - the human capital model and the migration model - across traditional and emerging destinations. Our findings suggest that while the predictions of the migration model are generally valid in explaining student emigration to non-English speaking OECD destinations, student flows to English speaking countries and emerging economies are largely in line with the predictions of the human capital model. The growing dispersion of international students to emerging economies and continuing large flows to English speaking countries are therefore indicative of the rising demand to acquire tertiary skills and much less of the desire to migrate for permanent settlement.
\end{abstract}

Neeraj Kaushal

Columbia University

School of Social Work

1255 Amsterdam Avenue

New York, NY 10027

and NBER

nk464@columbia.edu

Mauro Lanati

European University Institute

Villa Malafrasca, Via Boccaccio 151,

Florence 50133

Italy

mauro.lanati@eui.eu 


\section{Introduction}

Recent years have seen an unprecedented growth in international student flows and their geographic dispersion globally. In 2015, 4.6 million international students were enrolled worldwide, three-times the number in 1999 (UNESCO, 2018). This rise has been driven by students from emerging economies - such as India and China - predominantly moving to English - speaking OECD countries (Zong and Batlava, 2018; Figure 1). The United States continues to be the top destination, but its share has fallen from almost a third in 1999 to less than a quarter in 2015 (UNESCO, 2018). Meanwhile, several non-OECD countries have joined the ranks of top destinations with their combined share of international student flow rising to $28 \%$ in 2015 and China emerging as the third top destination. ${ }^{3}$

The growth and dispersion of international student flow has implications for both sending and destination countries. For destination countries, international students have become a major source of new talent, whose scarcity is widely considered the biggest threat to economic growth (Manpower Group, 2018, Gordon, 2012). To overcome the scarcity, many countries have special visas to facilitate entry of international students and several have instituted visas for their longterm settlement. For sending countries, the outflow of students for higher education creates issues of brain drain, in the short run, as many students decide to settle in destination countries permanently. In the long run, sending countries also benefit from brain regain as a substantial proportion of students return often with human capital they could not have acquired at home. Understanding the factors that influence these flows therefore has policy relevance for both origin and destination countries.

Previous research on international student mobility and its key determinants has generally focused on flows to rich countries (see for instance Beine, Noel and Ragot, 2014, Rosenzweig, 2008, Abbott and Silles, 2016). Restricting the choice of destination is likely to yield biased estimates as it involves using partial data on international student emigration. Further, these studies have diminished relevance in the current context as destinations for international students have grown in number and become geographically more diverse.

In this paper, we study international student flows to 141 destinations from 206 origin countries over a 16-year period to investigate the role of a number of time-varying origin and origin-destination specific factors across traditional and emerging destinations. We test the predictions of two primary models of international student mobility - the migration model and the human capital model - using empirical specifications that allow parsimonious (unrestricted) controls for observed and unobserved time-invariant origin-destination characteristics as well as time-varying destination-characteristics. Importantly, year-destination fixed effects allow controlling for time-varying destination visa policies, and destination-origin fixed effects allow controlling for visa restrictions that destinations impose on students from specific origins.

\footnotetext{
${ }^{3}$ The list of OECD countries refers to the ones that joined the group prior to 1995 (see Table A1).
} 
In addition to the aforementioned large sample of origin and destinations, we also study five destination clusters: (i) the top 25 destinations that received $88.5 \%$ of all international student flows during our study period; (ii) the top 25 non-OECD destinations (19.6\% of the international student flow); (iii) the top 25 OECD countries (77.7\% of the flow), which we further sub-divide into (iv) the six English speaking countries that have been traditional destinations for international students, namely the United States, the United Kingdom, Canada, Australia, Ireland, and New Zealand, (49.1\% of the flow) and (v) the top 19 non-English speaking OECD countries ( $28.6 \%$ of the flow).

Briefly, our findings suggest that while the predictions of the migration model are generally valid in explaining student emigration to non-English speaking OECD destinations, student flows to English speaking countries and emerging new destinations are largely in line with the predictions of the human capital model of mobility. The growing dispersion of international students to emerging economies and continuing large flows to English speaking countries are therefore indicative of the rising demand to acquire tertiary skills and much less of the desire to migrate for permanent settlement.

\section{Theoretical Issues:}

Economists have used human capital and migration models to study international student mobility (Beine et al., 2014, 2018; Rosenzweig, 2008). The human capital model postulates that education is an investment individuals make to maximize lifetime earnings (Becker, 1964). International students migrate to acquire skills or credentials that they cannot acquire at home. These credentials and skills improve employability in the labor market abroad as well as in the home country. Under the human capital model, students generally move to countries with education systems that have international recognition and provide skills that are portable. A large proportion of international students settle at the destination, but a substantial number also return to their origin countries.

The neoclassical model of migration, or what we call the migration model for brevity, on the other hand, postulates that individuals decide to emigrate to new destinations if the expected net difference in income between the destination and the origin is greater than the travel cost and other monetary and non-monetary costs of emigration (Todaro, 1969; Harris and Todaro, 1970). ${ }^{4}$ Student emigration, under this model, is primarily not for acquiring higher education but to eventually settle in the destination country on a permanent basis.

Rosenzweig and Beine and colleagues have extended the implications of the migration model in the context of international student mobility. The migration model is important because for residents of many developing countries who are keen on emigrating to rich countries it is easier to acquire a student visa than a visa for permanent emigration, which makes temporary

\footnotetext{
${ }^{4}$ There are a number of other theories of migration including Douglas Massey's cumulative causation theory. We focus on human capital and migration models, as we believe these models have greater relevance for international student mobility.
} 
migration using student visa an important means to enter and the first step towards eventual settlement in the destination country.

We study four dimensions of origin country characteristics and as we describe below there are similarities and differences in how the two models predict the association between the factors that measure these dimensions and international student mobility:

1. Inter-connectedness between sending and receiving countries, which we measure with two variables: immigrant networks of sending country population at the destination and volume of bilateral trade between sending and destination countries. Previous research suggests that presence of co-ethnic (or co-national) population (diaspora) lowers the cost of moving as well as eases assimilation at the destination. ${ }^{5}$ The migration model predicts a positive diaspora effect on future waves of migration, including international student flows. Diaspora effects are less strong under the human capital model because students in this model attach primary significance to knowledge acquisition and relatively less significance to permanent settlement.

The human capital model predicts strong positive relationship between bilateral trade and student mobility. High and rising bilateral trade between two nations create economic synergies that are best exploited with access to trading nation specific skills, including proficiency in trading nation language, managerial styles, technological advances. Thus increase in bilateral trade would increase demand for destination-specific skills. On the other hand, if the motive for mobility is permanent settlement bilateral economic relations, of which bilateral trade is an important aspect, may not be as significant a factor in international student mobility although it would continue to have a positive effect on student mobility.

2. Quality of Political and Administrative institutions in the origin country, measured with three variables: an index of political stability and absence of violence in the origin country, an index of voice and accountability, and government efficiency (see detailed description of these variables in Appendix Table 1). The migration model predicts a strong positive association between political instability and student outflow. An increase in government effectiveness will likely improve law-and order in the country, which may reduce incentives to emigrate to another country for permanent settlement under the migration model. Increases in political freedom and civil rights, captured by voice and accountability, will also reduce the incentive to migrate for reasons such as political coercion. The human capital model, on the other hand, predicts that increased political stability and absence of violence, government effectiveness and voice and accountability will increase returns to skills at the origin and therefore incentive to acquire them, including by traveling to foreign countries.

\footnotetext{
${ }^{5}$ Increased presence of co-nationals may also reduce the incentive to socially and culturally assimilate with the host country population.
} 
3. Educational infrastructure and demand for higher education at the origin: Educational infrastructure is measured with number of high-ranking universities in the country. Demand for higher education is measured with number of people in the country likely to seek college education (population in the official age for tertiary education), and share of graduates in the origin country's population. Both the human capital and migration models lead to similar predictions that poor educational infrastructure at origin and higher demand for education increase student mobility. Arguably, the association is likely to be stronger for the human capital model.

4. Economic growth at origin measured as per capita GDP at origin. The human capital and migration models predict a similar association between GDP growth and student mobility. The human capital model predicts that at low levels of GDP, an increase in GDP would incentivize students to go abroad for higher education due to lack of high quality institutions for higher education in the home country as well as increasing returns to higher education at home. As incomes rise, demand for higher-skilled workers rise and in response countries generally improve their educational quality, thus, after reaching a certain threshold of GDP the incentive to travel abroad for higher education will begin to dissipate if similar quality education could be acquired at home without incurring the financial and psychological costs of migration. In the migration model, in low-income countries, increases in per capita GDP will result in higher mobility indicating rising ability and aspirations of the sending country population to migrate. Student migration will plateau at a certain per capita GDP level beyond which any further increases in per capita GDP will result in lower mobility indicating that the usual incentives for emigration (more opportunities abroad) become less compelling.

\section{Previous Research}

In one of the earlier papers on student mobility, Bessey (2007) used five years of student inflow data (1997-2002) in Germany and found that many of the key determinants of immigrant location choices (e.g. immigrant networks, distance between origin and destination) were correlated with international student mobility. But home country disposable income was unrelated to student mobility; and student flow was less from countries with lower levels of political freedom. Rosenzweig (2008) studied student flows from Asian countries to the United States and found that while improvements in the quality of higher education at home reduced student outflows, increases in per capita number of colleges and universities were associated with higher student outflow.

Most studies on international student mobility are single-destination (e.g. the US, the UK, Italy or Germany) (Rosenzweig, 2008, Beine et al 2017, Beine et al 2018, Bessey, 2012). ${ }^{6}$ A

\footnotetext{
${ }^{6}$ Dreher and Pautvaara (2010) found that student migration has a positive impact on international migration. Using US State Department data on visas issued between 1992 and 2010 - Thomas and Inkpen (2016) - found that international student flows to the United States were particularly driven by a substantial growth in students on $\mathbf{J}$ visas, which requires the student to return to
} 
limitation of these studies is that they use partial data on international student flows from any origin country, which could result in biased estimates. For example, a study of sending country factors based on data on students from Asian countries to the United States does not capture the factors that led Asian students to choose other large destinations such as Australia, Japan, the U.K. and other European countries (see e.g. Rosenzweig, 2008).

A few recent studies used data on international student flows to multiple-destinations in OECD countries applying gravity models of mobility. ${ }^{7}$ Beine, Noel, and Ragot (2014) examined international student flows to 13-OECD countries during 2004-2007 and found that immigrant networks and quality of universities had large positive effects and cost factors such as housing prices had a negative effect on student location choices. Using student exchange data between 31 European countries, Van Bouwel and Veugelers (2013) also found that education quality had a positive effect on the size and direction of student flows overall. For graduate students, however, lack of educational opportunity at home was the driving force for student exchange between European countries. Gonzalez and Mesanza (2011), who studied Erasmus student mobility in Europe, found significant effects of cost of living differences and distance between sending and destination countries. ${ }^{8}$

Three studies expanded their framework to include non-OECD countries. Perkins and Neumayer (2014), used student inflow data for OECD and non-OECD countries during 20042009 , found that sending country university ranking had only a marginal impact on international student outflow. But their finding could be confounded by unobserved origin-year effects correlated with time-varying university rankings, which is also a weakness of Abbott and Silles (2016), who used 18 destination and 38 origin countries during 2005-2011, to study the role of destination-specific per capita GDP relative to origin per capita GDP. ${ }^{9}$ Wei (2012) examined the effect of economic and educational characteristics of destinations on international student flows in 48 countries during 1999-2008. A weakness of his regression analysis is that it did not control for destination country and year fixed effects and therefore, estimates were likely to be confounded by both time-invariant country fixed effects or country-invariant time effects.

We contribute to the existing literature in a number of ways: First, we study multipledestinations and multiple-origins over a 16-year panel, and an 11-year panel in some models. Data for multiple-destinations allows us to use models that capture a plethora of choices (host country-characteristics) that international students are likely to consider before moving. Using destination-origin dyadic fixed effects, we are able to account for, among other factors,

home country after completing their studies. Wu and Wilkes (2017) analyzed data from 232 interviews with international students from more than 50 countries who attended a flagship public university in Canada from 2006-2013 and found students who view home as a host plan to stay, and those who view home as ancestral plan to return, those with cosmopolitan and nebulous conceptions of home have more open migration plans.

${ }^{7}$ Gravity models have also been used to study inter-regional student flows within the same country. See for instance Agasisti and Dal Bianco (2007) for Italy, Alecke and Mitz (2013) and Bruckmeier et al. (2013) for Germany.

${ }^{8}$ However, Van Mol (2014) found that participation in the Erasmus programme did not increase student aspirations for international jobs.

${ }^{9}$ In all these studies, the standard gravity indicators of migration costs - such as physical distance and common language emerge as strong determinants of international student flows. In particular, migration costs matter more for student flows originating from developing countries (Perkins and Neumayer, 2014, Abbott and Silles, 2016). 
multilateral resistance to student emigration that arises from the fact that the choice of a potential student for a specific destination country depends not only on the attractiveness of the destination relative to the origin, but also on destination country attitudes and policies towards students from specific origins including visa policies. Failure to capture multilateral resistance may cause distortions in the estimated coefficients of gravity models (Bertoli and Fernandez-Moraga, 2013, Beine and Parsons, 2015, Ortega and Peri, 2013). In the empirical analysis, we include yeardestination fixed effects that allow us to control for, among other factors, time-varying destination visa policies, and destination-origin fixed effects that allow controlling for timeinvariant visa policies that many destination countries have for specific origin countries.

Second, we study several dimensions of origin country characteristics that are likely to impact student mobility and empirically test if our data validate the predictions from the migration model or the human capital model for the entire sample and across five geographic clusters of destination countries. If our study validates the human capital model it would imply that in the long run, sending countries would benefit from brain-regain. It also implies that international students are not a permanent source of talent at their chosen destinations.

Third, ours is the first study of student mobility to emerging non-OECD countries and non-English speaking destinations that captures the recent (post 2010) increases in dispersion of students across destinations. For comparison, we also study student mobility in traditional English speaking and non-English speaking OECD countries.

\section{Econometric Specification}

Our first objective is to study the association between time-varying bilateral dyadic specific characteristics, measuring interconnectedness between origin and destination countries, and international student mobility. Equation (1) describes our model specification:

$$
N_{i j t}=\alpha_{i j}+\alpha_{j t}+\alpha_{i t}+O D_{i j t-1} * \vartheta+e_{i j t}
$$

where $N_{i j t}$, the number of international tertiary-level students from origin country (i) who moved to destination country (j) in year $t$, is a function of origin-destination time-varying characteristics $\left(O D_{i j t-1}\right)$; a full set of origin-destination fixed effects $\left(\alpha_{i j}\right)$, origin-year fixed effects $\left(\alpha_{i t}\right)$, and destination-year fixed effects $\left(\alpha_{j t}\right)$, and $e_{i j t}$ denotes the error term. The timevarying dyadic factors $\left(O D_{i j t-c}\right)$ we include are the logarithm of the stock of immigrants born in country $i$ and resident in country $j$ to capture the diaspora effect, and the logarithm of aggregate bilateral trade (exports plus imports) flows between each origin-destination set. Both the variables are lagged. The bilateral stock of emigrants is lagged five years to partially address reverse causality between immigrant stock and student flow, and the trade variable by one year. For consistency, we also estimated models in which bilateral stock of immigrants was lagged by 
one year and the results were similar to those reported. ${ }^{10}$ Following Beine at al. $(2011,2014)$ who found that the diaspora effect manifested with a lag larger than one year, we present and discuss findings from models with the five-year lag of the immigrant stock variable.

The analysis is done by pooling multiple years of cross-sectional data. The inclusion of a large set of fixed effects allows us to estimate the association between international student flows and the two aforementioned time-varying origin-destination dyadic variables in a parsimonious manner. Origin-destination fixed effects $\left(\alpha_{i j}\right)$ control for time invariant dyadic associations such as geographic distance, religious and linguistic affinities, as well as certain hard to measure linkages including cultural similarities between the origin and the destination. Further, as Beine at al. (2014) argue destination countries may implement migration policies that favor (or disfavor) students from certain countries. Failing to control for $\alpha_{i j}$ may bias the estimates from equation (1). Destination-year fixed effects $\left(\alpha_{j t}\right)$ and origin-year fixed effects $\left(\alpha_{i t}\right)$ control for time varying destination and origin specific factors, observed as well as unobserved, that influence student mobility. Destination-year effects would include factors such as time-varying economic and policy changes. Origin-year effects would capture time-varying demographic changes such as sudden changes in cohort size of student age population and educational reforms.

Next, we study the impact of origin country characteristics, specifically economic development, educational infrastructure, and institutions of governance, on international student mobility. Equation (2) describes the empirical specification:

$$
N_{i j t}=\beta_{i j}+\beta_{i t}+O_{i t-1} * \pi+O D_{i j t-1} * \gamma+\epsilon_{i j t},
$$

Equation (2) differs from Equation (1) in one respect: it replaces origin-specific time fixed effects by the term $O_{i t-1}$, which encompasses a set of origin specific time-varying characteristics. ${ }^{11}$ This set includes institutional variables - namely Political Stability and Absence of Violence, Voice and Accountability, and Government Effectiveness; economic and demographic aspects of sending countries are per capita GDP, size of college-age population, and share of college graduates in total population; and variables capturing educational infrastructure at the origin, namely number of universities in origin country that are ranked among the Top500 universities in the world by the Shanghai Ranking and a dummy variable which takes the value of 1 if the country of origin has at least one university ranked among the Top 200. Similar to Rosenzweig (2008), share of graduates in total population captures the demand for higher education at origin and whether the origin country has a university ranked in the Top 200 measures quality of higher education institutions in the country of origin. Number of

\footnotetext{
${ }^{10}$ These results can be obtained from the authors upon request.

${ }^{11}$ Equation 2 is estimated using standard errors clustered at the origin level to address the potential correlation of the error term across $j$ for a given $i$.
} 
universities ranked in the Top 500 indicates the capacity of national universities with an international reputation to train students to the highest international standards and making them eligible for graduate training abroad.

We estimate equations (1) and (2) for the entire sample and also separately for the five destination clusters specified above to see if the associations qualitatively differ across these groups. Some of the variables on educational infrastructure in the origin country are not available for 2004 or earlier years; therefore the analyses in equation (2) is conducted using post-2004 data. Because international student flows are largely to a small number of countries, our dataset includes a relatively large number of zeros (around 31 percent of total observations). Hence, taking logs of student emigration in the dependent variable is likely to cause a considerable loss of information that could create biased results due to possible selection bias. We use Poisson PML (PPML), which provides consistent estimates in the presence of heteroscedasticity and performs well when the dependent variable has a relatively large number of zeros (Santos Silva \& Tenreyro 2006, 2011). We also did separate analyses excluding observations indicating zero flows (see Table A4 in the Appendix): the PPML estimates were fairly similar to those reported, suggesting that our estimates were not biased by the presence of origin-destination countries with zero flows. $^{12}$

\section{Data}

The sample of our empirical analysis includes 141 migrant destination countries and 206 migrant origin countries covering the period 1999- 2015.

Dependent Variable: Annual Data on the international students from origin country $i$ to destination country $j$ are from the UIS UNESCO Dataset. UNESCO data on student inbounds exclude China, which is attracting an increasingly large number of foreign university students in recent years. For our regression analysis, we integrate data on Chinese inflows of tertiary educated students from the Chinese Ministry of Foreign Affairs that are available from 2011 with the UNESCO data. ${ }^{13}$

Dyadic Factors: The Bilateral Stocks of Immigrants born in country $i$ and resident in country $j$ in year t-1 and t-5 are from the World Bank Bilateral Migration Dataset. The World Bank provides these data for a limited number of years. ${ }^{14}$ In order to match the information on migrant networks

\footnotetext{
${ }^{12}$ PPML estimator has been used in previous studies, which look at the determinants of student mobility using a gravity model (see Abbott and Silles, 2016, Beine et al 2014, Beine et al 2018). PPML produces consistent estimates only if the error terms satisfy the log normality and homoscedasticity conditions, which are indeed strong assumptions (see Aleksinska and Peri 2014, for a discussion). As a robustness check, we estimate Equations 1 \& 2 using ordinary least squares and find similar that are quantitatively and qualitatively similar. The results are available upon request.

${ }^{13}$ As a robustness check we estimate Equation 2 - that includes both dyadic as well as origin specific determinants - on a sample restricted to 2011-2015. The results - available upon request - are similar to the ones presented in this paper.

14 The cross sections are for the years 1960, 1970, 1980, 1990, 2000, 2010, 2013 and $2017 . \quad$ See http://www.worldbank.org/en/topic/migrationremittancesdiasporaissues/brief/migration-remittances-data
} 
with student mobility we have linearly interpolated observations to fill in missing values in intermediate years. Aggregate Bilateral Trade is from the Base Pour l'Analyse du Commerce International (BACI) dataset from the Centre d'études prospectives et d'informations internationales (CEPII) and is the sum of annual bilateral imports and exports expressed in current US dollars.

Origin Specific Factors: GDP per capita, in 2011 PPP constant dollars, is from the World Bank, Population in tertiary-education age is from UNESCO Institute for Statistics. As for the quality of governance in country of origin, we include the World Bank's index of Political Stability and Absence of Violence/Terrorism that measures the perceptions of the likelihood of political instability and/or politically-motivated violence, including terrorism. Voice and Accountability captures citizens' perceptions of their ability to participate in selecting their government, as well as freedom of expression, freedom of association, and a free media in the country. Government Effectiveness captures public perceptions of the quality of public services, civil service and independence from political pressures, and the credibility of the government's commitment to public policies. ${ }^{15}$ The variables capturing the quality of tertiary education in country of origin are from the Shanghai Ranking of World Universities, which provides data on world rankings from 2004. A complete list of variables, including brief descriptions and sources, is in Table A2.

\section{Results}

\section{Descriptive Analysis}

Figure 1 presents the trend in the number of international students over the 17 years period covered in this study, from 1999-2015, for the entire sample and the five sub-groups of clusters. China is excluded as destination in this figure because inflow data for China prior to 2011 is not available. There are a few points to note. One, student mobility has markedly increased during our study period with the number of international students rising from approximately 1.3 million in 1999 to 4.1 million in 2015. Two, international students mobility indicates an unprecedented degree of dispersion. In 1999, $88 \%$ of the international students chose the top 25-OECD countries and less than 6\% chose the top 25 non-OECD countries as destinations. By 2015, the share of the top-25 OECD countries had fallen to $67 \%$ and of the top non-OECD countries had increased to $28 \%$. Three, throughout the 17 -year period, the top six English speaking countries received a lion's share of the international student flow, although the trend suggests a decline over time from $58 \%$ in 1999 to $48 \%$ in 2015.

\footnotetext{
15 These World Governance Indicators (WGI) are constructed by the World Bank averaging data from the following sources surveys of households and firms, commercial business information providers, non-governmental organizations and public sector organizations. These indicators are reported in their standard normal units, ranging from approximately -2.5 to 2.5 . More information on how these indexes are constructed is available at http://info.worldbank.org/governance/wgi/\#doc-methodology
} 
Table 1 lists the top 15 destinations in 2000, 2005, 2010, and 2015 and documents a rising number of non-OECD countries among these top destinations over time. Flows of international students to English-speaking countries have continued to grow, but the pace is much subdued compared to the overall growth in international students. Further, a few nonEnglish speaking OECD countries, including Germany and Japan, experienced a fall in the inflow of international students in recent years, indicating the primacy of the English language in higher learning and global high-skilled professions and the rise of emerging economies as new destinations. ${ }^{16} \mathrm{~A}$ number of Asian countries have joined the ranks of the top destinations with China emerging as the third most favorable destination, hosting around 400,000 international students in 2015. ${ }^{17}$ Improvements in the quality of Asian universities as well as increasing economic opportunities in Asia are the likely factors that explain this trend (see Beine et al., 2014).

\section{Trends in Quality of Education}

Data from the Shanghai Ranking of World Universities show an increase in the share of emerging economies, especially Asian economies, among the top ranked global universities (Figure 2). During 2005-2018 the share of Top 500 and Top 200 universities in the Asia Pacific region has increased from $18 \%$ to $27 \%$ and from $11 \%$ to $21 \%$, respectively. Asia's gain has been at the expense of European and American universities. China, followed by Singapore, Russia, Saudi Arabia, and South Korea are driving this trend with the number of Top 500 ranking universities in Asia rising from 35 to 94 . The rising quality in tertiary education is enabling Asian countries to both directly compete with traditional English speaking destinations in attracting talent as well as train their native students to high international standards and making them eligible for graduate training abroad.

\section{International Student Mobility and Per Capita GDP Growth at Origin}

Existing research does not provide any clear guide on whether the association between international student mobility is linear or nonlinear. Clemens (2014) finds the association between emigration and origin country per capita GDP to be inverted U-shape. Dao et al. (2018, Figure 2b), on the other hand, using a sample of 123 countries of origin find that college educated migration rates decrease with development. In Figure (3), we plot the cross-sectional association between international student mobility rate (normalized by population) and origin country per capita income for the top 25 sending countries, that received $88.5 \%$ of all international student flows during our study period, using non-parametric regressions. We find

\footnotetext{
${ }^{16}$ Recent literature has identified student desire to improve their linguistic skills - particularly English language - as one of the prominent motivations for study abroad (Kahanec and Králiková, 2011). Also see Medrano (2016) on the positive relationship between fluency in English and employment status in EU countries.

${ }^{17}$ In 2015 Chinese students represented $17.6 \%$ of total international student emigrants.
} 
evidence of an inverted U-Shape for most of the yearly cross-sections as predicted by both the human capital and migration models of student mobility.

\section{Regression Analysis}

Table 2 reports estimates based on Equation (1). Column 1 suggests that both measures of inter-connectedness - co-national density and bilateral trade - positively influence student mobility. A one percent increase in co-national density (or what we call diaspora effect) is associated with a three percent increase in student inflow and a one percent increase in trade is associated with a one percent increase in student flow.

Estimates differ across destination clusters. The effect size of the diaspora variable is larger when models are restricted to the top 25 destinations as well as the top 25 OECD destinations. Estimated effects are statistically insignificant for English speaking countries. One likely explanation for this finding is the education quality and international reputation of universities in the six English speaking countries (Australia, New Zealand, Ireland, the United States, Canada and the United Kingdom) and the associated skill prices that make these countries universally appealing, reducing the role of diaspora and bilateral trade in attracting inflows. Note that with English being the global language, education in English-speaking countries is globally more portable, and therefore less risky, than education in non-English speaking countries.

For non-OECD countries (column 6) - which include new student destinations such as China, India, Malaysia, Saudi Arabia, and United Arab Emirates - our estimates suggest that bilateral trade has a substantial role in creating student flows, but diaspora has a negligible role. Lack of diaspora effects in the top 25-non-OECD countries weakens the validity of the migration model and suggests that the growing dispersion of international students to emerging economies is indicative of the rising demand to acquire global tertiary skills and much less of the desire to migrate for permanent settlement to escape poverty and political coercion.

We also estimate Equation (1) using models that replace country pair fixed effects with a number of origin-destination characteristics (Appendix Table A3). These models are comparable to those in previous research. In these models, even for the top 25-nonOECD countries the diaspora effects are positive, as documented in previous studies (see Perkins and Neumayer 2014 and Beine et al 2014). However, we believe that our more parsimonious model in Table 2 is superior to the model used in Appendix Table A3.

One criticism of the models in Table 2 is that for many origin-destination groups the student flow is zero and presence of a large number of zeros might bias our estimates. We reestimated the models in Table 2 after excluding observations with zero flows. Results presented

in Appendix Table A4 are similar to those in Table 2 suggesting that the presence of zero flows has not qualitatively affected our estimates.

Table 3 shows estimates based on Equation (2). We present two models for the entire sample and for each country-cluster. In model $1, \log$ of income per capita is a linear variable and in model 2, it is introduced as a quadratic. For the entire sample, the association can be 
interpreted as weakly quadratic suggesting that student mobility rises with income and plateaus or begins to decline at very high incomes, as shown in Figure 3. However, the link between per capita income and student mobility differs across samples. In samples restricted to English speaking destination countries, student flow monotonically increases with the log of income per capita at origin, suggesting that even students from very high income countries (e.g. Japan, Germany) expect returns to education acquired in English speaking countries (relative to home country) to remain positive. Our estimates show the classic inverted U-shaped link between per capita income and student mobility for the top 25 destinations and a weak quadratic link for students moving to the top non-English speaking OECD countries and the top 25 non-OECD destinations.

Note that these regressions control for home country educational infrastructure, which is likely correlated with GDP. We also estimated models without including sending country educational infrastructure variables, and the estimated coefficients on the GDP variable were similar to those reported from models that included these controls.

As for the quality of education at the origin, our estimates generally suggest that number of universities in the sending country that are ranked among the Top 500 has a positive impact on student mobility, but the effects are statistically insignificant in samples restricted to flows to non-English speaking top OECD countries and non-OECD countries. The presence of a university among the top 200 world universities in the sending country generally has a negative effect on student mobility, but the estimated effect is statistically significant only for arrivals in non-English-speaking OECD and non-OECD countries.

Estimates in Table 3 indicate that sending country population in the tertiary age group has no statistically significant association with student outflow. The association between number of graduates in the sending country and international student outflow is also insignificant except when the sample is restricted to non-OECD destinations, where the relationship is negative. One possible explanation could be that student emigration to non-OECD countries is more likely for undergraduate or graduate education and less for post-graduate education.

In Table 4, we include controls for sending country characteristics that capture quality of administrative and political institutions in the sending country. Generally speaking, estimates are robust to the inclusion of these controls. ${ }^{18}$ Among the institutional variables, the results suggest that more politically stable countries are associated with lower outflows of students when we consider non-OECD destinations whereas improvement in quality of governance at the origin increased student flow to English speaking destinations.

\footnotetext{
${ }^{18}$ Dao et al (2018) showed that macroeconomic drivers of migration - that do not change in the short-run - are among the most important factors which explain the upper segment of the mobility transition curve.
} 


\section{Concluding Remarks}

In this paper, we tested the theoretical predictions of the human capital and migration models on the determinants of international student mobility on a sample of 141 destination countries and 206 origin countries spanning a period of 17 years. We also estimate empirical models across five types of destination clusters: top 25 destinations; top 25 OECD countries, sixEnglish-speaking destinations; top 19 non-English-speaking OECD countries; and top 25 nonOECD countries. Time series data on multiple origins and destinations allow use of parsimonious models with unrestricted controls for observed and unobserved time-invariant origin-destination characteristics as well as time-varying destination- and origin-characteristics.

Several interesting findings emerge. The association between international student flow and co-ethnic density of immigrants, or what we call the diaspora effect, varies across destinations. It is large and positive for inflows to top non-English speaking OECD destinations, but statistically insignificant to English speaking countries and non-OECD destinations. One important inference that can be drawn from these findings is that while student flows to the top non-English speaking OECD countries validate the migration model of mobility, student flows to the top non-OECD countries and English speaking countries do not. Estimates for the latter two clusters of countries validate the human capital model. This suggests that the predominance of English speaking destinations and the growing dispersion of international students to emerging economies is indicative of the rising demand to acquire global tertiary skills and much less of the desire to migrate for permanent settlement to escape poverty and political coercion.

Our estimates show the classic inverted U-shaped link between per capita income and student mobility for the top non-English speaking OECD destinations and a weak quadratic link for students moving to the top non-OECD destinations. In samples restricted to English Speaking destination countries, student flow monotonically increases with the log of income per capita at origin, suggesting that students from even very high-income countries (e.g. Japan, Germany) expect the returns to education acquired in English speaking countries (relative to home country) to remain positive.

Our estimates of the association between educational infrastructure at origin and student outflow yield expected estimates, but do not strongly validate either the human capital or the migration model. The quality of education at the origin, measured using the number of universities in the sending country that are ranked in the Top 500, has a positive impact on student mobility, but the effects are statistically insignificant in samples restricted to flows to non-English speaking top OECD destinations and top non-OECD destinations. The presence of a university among the top 200 world universities in the sending country, as expected, generally has a negative effect on student mobility, but the estimated effect is statistically significant only for arrivals in non-English-speaking OECD and non-OECD countries. Estimates remain robust to inclusion of controls that capture quality of administrative and political institutions in the sending country. Among the institutional variables, our results suggest that more politically stable countries are associated with lower outflows of students when we consider non-OECD 
destinations whereas improvement in quality of governance at the origin increased student flow to English Speaking destinations.

These findings have important policy implications for both sending and destination countries. Importantly, our results suggest that emergence of new destinations for international students in non-OECD countries portend increase in competition for talent not just among rich OECD countries but also emerging economies. Evidence validating predictions of the human capital model suggests that sending countries can contain the student outflow by strengthening their educational infrastructure or increase return of their nationals by improving governance and accountability and increasing political stability. 


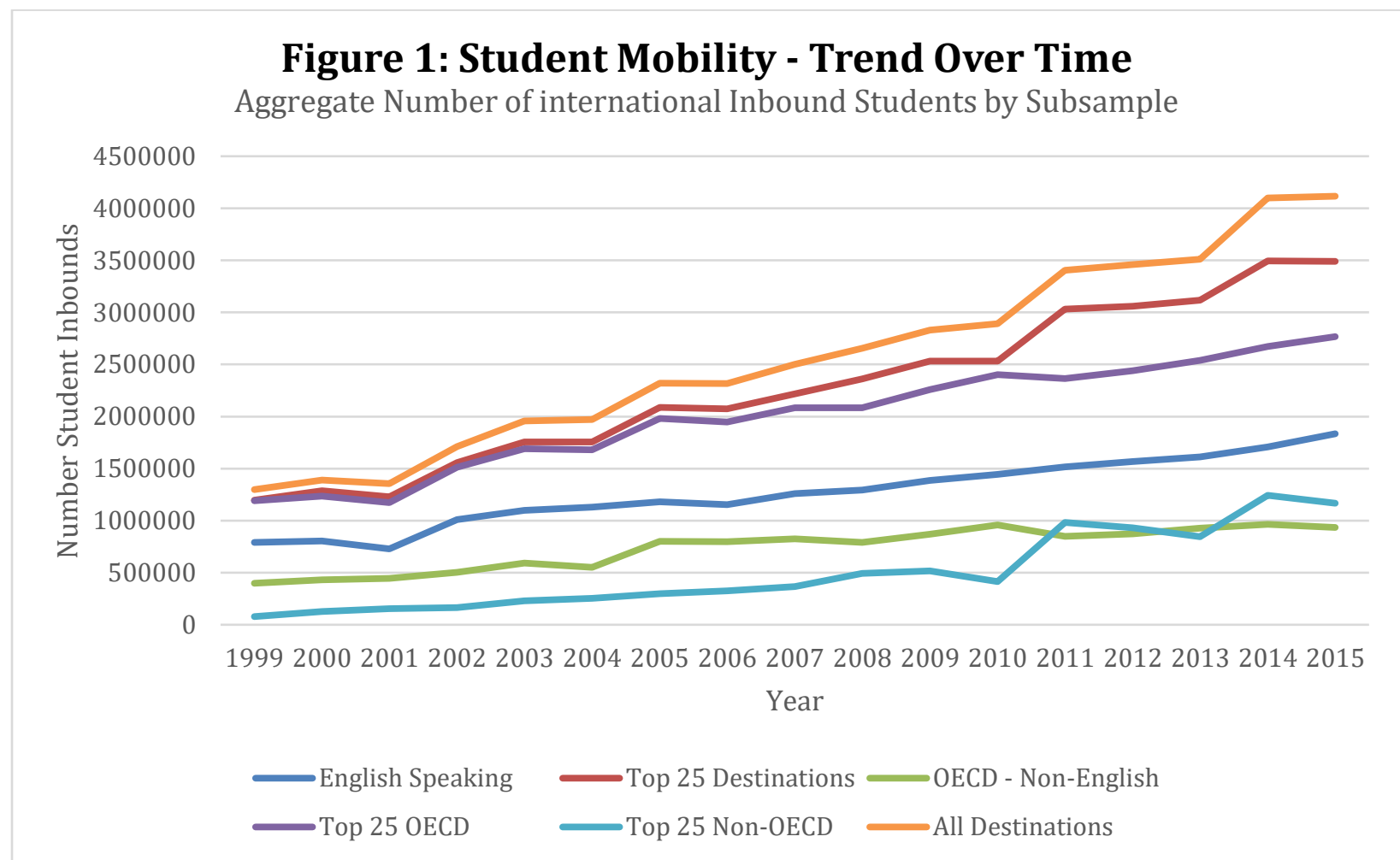

Notes: The graph reports the trend over time of the aggregate number of inbound tertiary educated students by destination clusters. These statistics are obtained by aggregating all the bilateral flows of student inbounds for which we have data by destination. The country composition of each subsample is showed in Table A1. Source: UIS UNESCO. 
Figure 2 - Share of Top Universities by Region

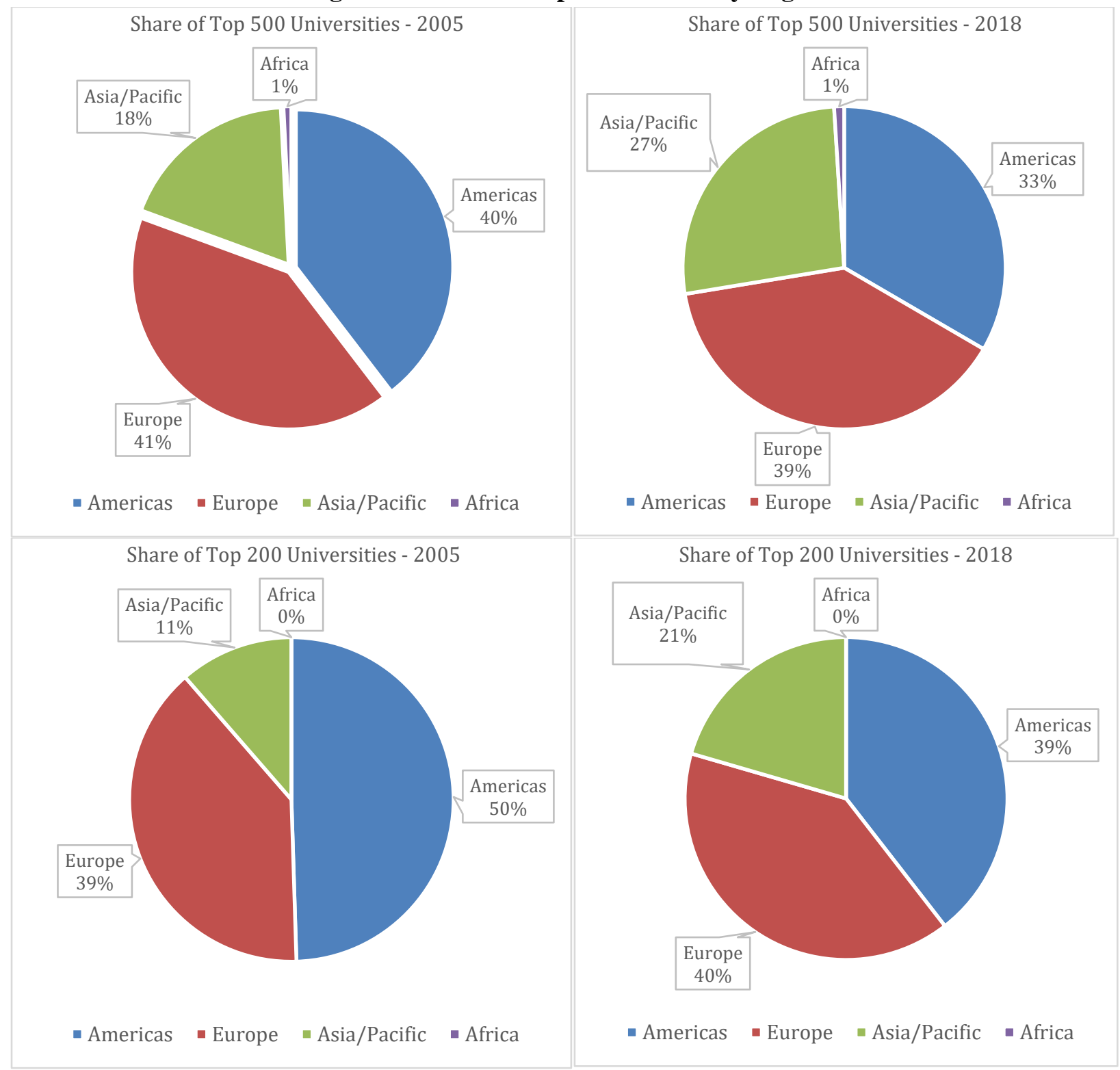

Notes: Data are from Shanghai World University Rankings. 
Figure 3 - Cross-Section Nonparametric Regressions of Student Emigrant Rate on Real Income per capita, 2000-2015

Sample: Top 25 Sending Countries in 2005

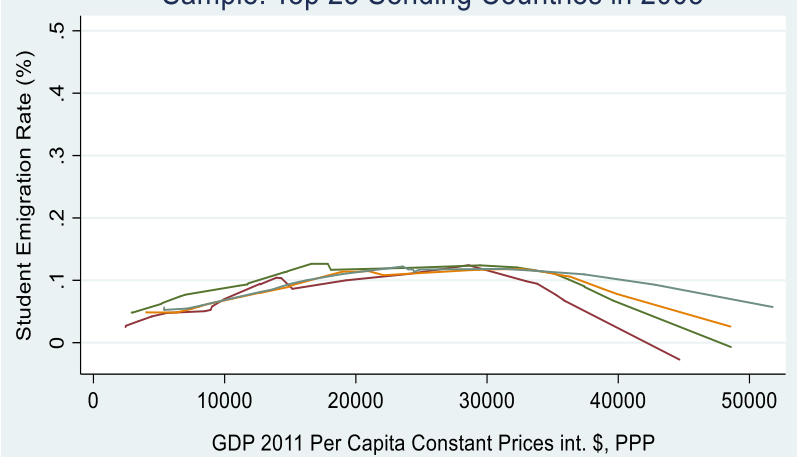

GDP 2011 Per Capita Constant Prices int. \$, PPP

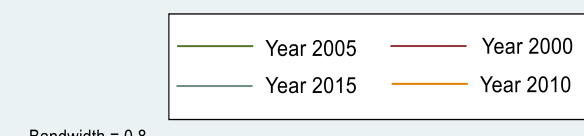

Sample: Top 25 Sending Countries in 2010

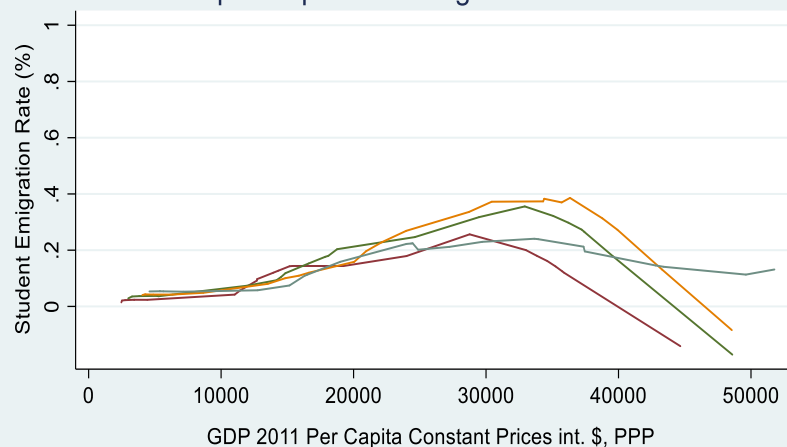

Bandwidth $=0.8$

Note: Lowess smoothing on the top 25 sending countries in 2005 (left) and in 2010 (right). Hong Kong is excluded as it has unusually large emigration rates compared to its population. Emigration rates are constructed as the total number of student emigrants to all destinations normalized by country's population. 
Table 1: Top 15 Destinations

\begin{tabular}{|c|c|c|c|c|c|c|c|}
\hline Country & $\begin{array}{l}\text { Year } \\
2000\end{array}$ & Country & $\begin{array}{l}\text { Year } \\
2005\end{array}$ & Country & $\begin{array}{l}\text { Year } \\
2010\end{array}$ & Country & $\begin{array}{l}\text { Year } \\
2015\end{array}$ \\
\hline Turkey & 17643 & Ukraine & 18997 & Czech Republic & 34666 & Austria & 65805 \\
\hline Sweden & 20647 & Jordan & 20606 & Switzerland & 37301 & Turkey & 71848 \\
\hline Italy & 21250 & Kyrgyzstan & 23458 & New Zealand & 37880 & United Arab Emirates & 72968 \\
\hline Switzerland & 24875 & Switzerland & 36710 & Spain & 55696 & Saudi Arabia & 73076 \\
\hline South Africa & 25581 & New Zealand & 40778 & South Africa & 57321 & Italy & 90256 \\
\hline Austria & 30226 & South Africa & 42290 & Republic of Korea & 59194 & Malaysia & 111324 \\
\hline Canada & 34491 & Italy & 42638 & Italy & 61227 & Japan & 131969 \\
\hline Belgium & 37986 & Russian Federation & 48881 & Austria & 68570 & Canada & 162930 \\
\hline Spain & 40689 & Canada & 67776 & Canada & 98184 & Russian Federation & 209085 \\
\hline Russian Federation & 41210 & Japan & 125902 & Japan & 141561 & Germany & 212295 \\
\hline Japan & 59682 & Australia & 167246 & Germany & 185622 & France & 224280 \\
\hline Australia & 93458 & France & 211692 & France & 242948 & Australia & 291950 \\
\hline France & 136171 & Germany & 257815 & Australia & 251306 & China & 396517 \\
\hline UK & 222203 & UK & 310879 & UK & 391415 & UK & 430632 \\
\hline USA & 475169 & USA & 590120 & USA & 684517 & USA & 907047 \\
\hline
\end{tabular}

Notes: The top Non-OECD destinations are in bold. UIS UNESCO Statistics do not provide information on Student Inbounds for Germany prior to 2004. Data on Chinese inflows of tertiary educated students are from the Chinese Ministry of Foreign Affairs that are only available from 2011 onwards. 
Table 2: Estimated Association between Dyadic Time Varying Origin-Destination Characteristics and International Student Mobility (Poisson PML Model: Dependent Variable International Student Inbounds in,t)

\begin{tabular}{|c|c|c|c|c|c|c|}
\hline Sample (Destination Countries)/ & $\begin{array}{c}(1) \\
\text { Entire Sample }\end{array}$ & $\begin{array}{c}(2) \\
\text { Top 25 } \\
\text { Destinations }\end{array}$ & $\begin{array}{c}\text { (3) } \\
\text { English Speaking } \\
\text { Destinations }\end{array}$ & $\begin{array}{c}(4) \\
\text { Top 19 OECD } \\
\text { Non-English } \\
\text { Countries }\end{array}$ & $\begin{array}{c}5) \\
\text { Top 25 OECD } \\
\text { Destinations }\end{array}$ & $\begin{array}{c}\text { (6) } \\
\text { Top 25 Non-OECD } \\
\text { Destinations }\end{array}$ \\
\hline Log Stock Emigrants in, t-5 & $\begin{array}{c}0.0268^{*} \\
(1.98)\end{array}$ & $\begin{array}{c}0.0526^{* *} \\
(3.15)\end{array}$ & $\begin{array}{l}0.0428 \\
(1.41)\end{array}$ & $\begin{array}{l}0.178^{* * *} \\
(5.51)\end{array}$ & $\begin{array}{c}0.0630^{* *} \\
(2.77)\end{array}$ & $\begin{array}{c}-0.0209 \\
(-1.50)\end{array}$ \\
\hline Log Trade Total in,t-1 & $\begin{array}{c}0.00891^{* *} \\
(3.28)\end{array}$ & $\begin{array}{c}0.00561^{*} \\
(2.09)\end{array}$ & $\begin{array}{l}0.0322 \\
(1.86)\end{array}$ & $\begin{array}{l}0.0282^{*} \\
(2.50)\end{array}$ & $\begin{array}{l}0.0262^{*} \\
(2.54)\end{array}$ & $\begin{array}{c}0.0104^{* *} \\
(3.00)\end{array}$ \\
\hline $\begin{array}{l} \\
\text { Dest } * \text { Year Fixed Effects } \\
\text { Dest*Origin Fixed Effects } \\
\text { Origin*Year Fixed Effects } \\
\text { Origin Countries } \\
\text { Dest. Countries } \\
\text { Zeros }\end{array}$ & $\begin{array}{l}153816 \\
X \\
X \\
X \\
141 \\
206 \\
48,605\end{array}$ & $\begin{array}{c}67303 \\
X \\
X \\
X \\
26 \\
206 \\
13,073\end{array}$ & $\begin{array}{c}18995 \\
X \\
X \\
X \\
6 \\
206 \\
2,294\end{array}$ & $\begin{array}{c}7410 \\
X \\
X \\
X \\
19 \\
202 \\
14,264\end{array}$ & $\begin{array}{c}66627 \\
X \\
X \\
X \\
25 \\
206 \\
11,992\end{array}$ & $\begin{array}{c}45006 \\
X \\
X \\
X \\
25 \\
206 \\
15,434\end{array}$ \\
\hline
\end{tabular}

Notes: $t$ statistics are in parentheses; ${ }^{*} p<0.05,{ }^{* *} p<0.01,{ }^{* * *} p<0.001$. Standard Errors are clustered by country-pair.

Estimates are obtained using the Stata Command ppml_panel_sg to estimate Poisson PML gravity specifications. The dependent variable is the number of inbound tertiary educated students for 19992015. Column heading describes the sample. Figures reported in the Table are estimates of Equation (1). See Appendix Table 2 for the description of explanatory variables listed in column 1. 
Table 3: Estimated Association between Origin-Country Characteristics and International Student Mobility

(Poisson PML Model: Dependent Variable International Student Inbounds in, )

\begin{tabular}{|c|c|c|c|c|c|c|c|c|c|c|c|c|}
\hline Sample (Destinations) & $\begin{array}{c}(1) \\
\text { Entire } \\
\text { Sample }\end{array}$ & $\begin{array}{c}(2) \\
\text { Entire } \\
\text { Sample }\end{array}$ & $\begin{array}{c}\text { (3) } \\
\text { Top } 25\end{array}$ & $\begin{array}{c}(4) \\
\text { Top 25 }\end{array}$ & $\begin{array}{c}\text { (5) } \\
\text { English } \\
\text { Speaking }\end{array}$ & $\begin{array}{c}6) \\
\text { English } \\
\text { Speaking }\end{array}$ & $\begin{array}{c}(7) \\
\text { OECD } \\
\text { Non- } \\
\text { English } \\
\end{array}$ & $\begin{array}{c}(8) \\
\text { OECD } \\
\text { Non- } \\
\text { English } \\
\end{array}$ & $\begin{array}{c}\text { (9) } \\
\text { Top 25 } \\
\text { OECD }\end{array}$ & $\begin{array}{c}(10) \\
\text { Top 25 } \\
\text { OECD }\end{array}$ & $\begin{array}{c}\text { (11) } \\
\text { Top 25 } \\
\text { Non- } \\
\text { OECD }\end{array}$ & $\begin{array}{c}(12) \\
\text { Top 25 } \\
\text { Non- } \\
\text { OECD }\end{array}$ \\
\hline Log Stock Emigrants in, t-5 & $\begin{array}{c}0.0518^{*} \\
(2.47)\end{array}$ & $\begin{array}{c}0.0501^{*} \\
(2.36)\end{array}$ & $\begin{array}{c}0.0705^{* *} \\
(2.75)\end{array}$ & $\begin{array}{c}0.0673^{* *} \\
(2.60)\end{array}$ & $\begin{array}{l}0.142^{*} \\
(2.20)\end{array}$ & $\begin{array}{l}0.141^{*} \\
(2.14)\end{array}$ & $\begin{array}{c}0.0786 \\
(1.81)\end{array}$ & $\begin{array}{c}0.0699 \\
(1.58)\end{array}$ & $\begin{array}{c}0.114^{* *} \\
(2.78)\end{array}$ & $\begin{array}{c}0.110^{* *} \\
(2.67)\end{array}$ & $\begin{array}{c}0.0188 \\
(0.99)\end{array}$ & $\begin{array}{c}0.0183 \\
(0.98)\end{array}$ \\
\hline Log Trade Total in,t-1 & $\begin{array}{c}0.00384 \\
(1.32)\end{array}$ & $\begin{array}{c}0.00362 \\
(1.27)\end{array}$ & $\begin{array}{c}0.00308 \\
(1.17)\end{array}$ & $\begin{array}{c}0.00258 \\
(1.04)\end{array}$ & $\begin{array}{c}0.0137 \\
(0.86)\end{array}$ & $\begin{array}{c}0.0110 \\
(0.74)\end{array}$ & $\begin{array}{r}-0.0247 \\
(-0.81)\end{array}$ & $\begin{array}{c}-0.0259 \\
(-0.87)\end{array}$ & $\begin{array}{c}0.00670 \\
(0.53)\end{array}$ & $\begin{array}{c}0.00520 \\
(0.43)\end{array}$ & $\begin{array}{c}0.00330 \\
(1.42)\end{array}$ & $\begin{array}{c}0.00330 \\
(1.38)\end{array}$ \\
\hline \multicolumn{13}{|l|}{ Origin characteristics: } \\
\hline Log GDP ppp p $c_{n, t-1}$ & $\begin{array}{c}0.516^{* * *} \\
(3.47)\end{array}$ & $\begin{array}{l}2.747^{*} \\
(2.06)\end{array}$ & $\begin{array}{c}0.605^{* * *} \\
(3.62)\end{array}$ & $\begin{array}{l}3.091^{*} \\
(2.17)\end{array}$ & $\begin{array}{c}0.817^{* * *} \\
(3.65)\end{array}$ & $\begin{array}{l}3.081 \\
(1.69)\end{array}$ & $\begin{array}{l}0.184 \\
(1.19)\end{array}$ & $\begin{array}{l}2.172 \\
(1.40)\end{array}$ & $\begin{array}{c}0.586^{* *} \\
(3.25)\end{array}$ & $\begin{array}{l}2.383 \\
(1.48)\end{array}$ & $\begin{array}{l}-0.449 \\
(-1.80)\end{array}$ & $\begin{array}{l}3.298 \\
(1.88)\end{array}$ \\
\hline$\left(\log \text { GDP ppp pc } c_{n, t-1}\right)^{2}$ & & $\begin{array}{l}-0.123 \\
(-1.74)\end{array}$ & & $\begin{array}{l}-0.137 \\
(-1.81)\end{array}$ & & $\begin{array}{l}-0.124 \\
(-1.31)\end{array}$ & & $\begin{array}{l}-0.109 \\
(-1.28)\end{array}$ & & $\begin{array}{c}-0.0988 \\
(-1.16)\end{array}$ & & $\begin{array}{l}-0.208^{*} \\
(-2.12)\end{array}$ \\
\hline Log Population $_{n, t-1}$ & $\begin{array}{l}0.155 \\
(0.71)\end{array}$ & $\begin{array}{l}0.135 \\
(0.61)\end{array}$ & $\begin{array}{l}0.212 \\
(0.87)\end{array}$ & $\begin{array}{l}0.196 \\
(0.80)\end{array}$ & $\begin{array}{l}0.146 \\
(0.52)\end{array}$ & $\begin{array}{l}0.146 \\
(0.52)\end{array}$ & $\begin{array}{l}0.112 \\
(0.58)\end{array}$ & $\begin{array}{c}0.0691 \\
(0.37)\end{array}$ & $\begin{array}{l}0.126 \\
(0.52)\end{array}$ & $\begin{array}{l}0.116 \\
(0.47)\end{array}$ & $\begin{array}{l}0.316 \\
(1.31)\end{array}$ & $\begin{array}{l}0.231 \\
(1.00)\end{array}$ \\
\hline Share of Graduates. $n, t-1$ & $\begin{array}{l}-7.014 \\
(-0.84)\end{array}$ & $\begin{array}{l}-6.803 \\
(-0.86)\end{array}$ & $\begin{array}{l}-7.318 \\
(-0.73)\end{array}$ & $\begin{array}{l}-7.254 \\
(-0.77)\end{array}$ & $\begin{array}{l}2.594 \\
(0.19)\end{array}$ & $\begin{array}{l}0.799 \\
(0.07)\end{array}$ & $\begin{array}{l}-4.833 \\
(-0.46)\end{array}$ & $\begin{array}{l}-3.432 \\
(-0.33)\end{array}$ & $\begin{array}{l}-2.093 \\
(-0.19)\end{array}$ & $\begin{array}{l}-2.293 \\
(-0.22)\end{array}$ & $\begin{array}{c}-36.75^{* *} \\
(-3.05)\end{array}$ & $\begin{array}{c}-32.91^{* *} \\
(-2.73)\end{array}$ \\
\hline $\begin{array}{l}\text { Log Number of Univ. } \\
\text { among Top } 500_{n, t-1}\end{array}$ & $\begin{array}{l}0.359^{*} \\
(2.20)\end{array}$ & $\begin{array}{l}0.388^{*} \\
(2.44)\end{array}$ & $\begin{array}{l}0.347^{*} \\
(2.01)\end{array}$ & $\begin{array}{l}0.379^{*} \\
(2.24)\end{array}$ & $\begin{array}{l}0.440^{*} \\
(2.05)\end{array}$ & $\begin{array}{l}0.474^{*} \\
(2.31)\end{array}$ & $\begin{array}{c}0.0494 \\
(0.36)\end{array}$ & $\begin{array}{c}0.0583 \\
(0.42)\end{array}$ & $\begin{array}{l}0.378^{*} \\
(2.06)\end{array}$ & $\begin{array}{l}0.401^{*} \\
(2.26)\end{array}$ & $\begin{array}{l}0.123 \\
(1.39)\end{array}$ & $\begin{array}{l}0.176 \\
(1.87)\end{array}$ \\
\hline $\begin{array}{l}\text { Any Ranked Univ.n.,-1 } \\
\text { (among the top 200) }\end{array}$ & $\begin{array}{c}0.0255 \\
(0.30)\end{array}$ & $\begin{array}{c}0.0399 \\
(0.49)\end{array}$ & $\begin{array}{c}0.0308 \\
(0.36)\end{array}$ & $\begin{array}{c}0.0464 \\
(0.56)\end{array}$ & $\begin{array}{c}0.0824 \\
(0.91) \\
\end{array}$ & $\begin{array}{r}0.0921 \\
(1.03) \\
\end{array}$ & $\begin{array}{c}-0.0902^{*} \\
(-2.16)\end{array}$ & $\begin{array}{c}-0.0758 \\
(-1.79)\end{array}$ & $\begin{array}{c}0.0504 \\
(0.55) \\
\end{array}$ & $\begin{array}{c}0.0613 \\
(0.68)\end{array}$ & $\begin{array}{l}-0.195^{*} \\
(-2.52) \\
\end{array}$ & $\begin{array}{l}-0.172^{*} \\
(-2.08)\end{array}$ \\
\hline$N$ & 57191 & 57191 & 24041 & 24041 & 6293 & 6293 & 16716 & 16716 & 23054 & 23054 & 17517 & 17517 \\
\hline Dest*Year FE & $\mathrm{X}$ & $\mathrm{X}$ & $\mathrm{X}$ & $\mathrm{X}$ & $\mathrm{X}$ & $\mathrm{X}$ & $\mathrm{X}$ & $\mathrm{X}$ & $\mathrm{X}$ & $\mathrm{X}$ & $\mathrm{X}$ & $\mathrm{X}$ \\
\hline Dest*Origin FE & $\mathrm{X}$ & $\mathrm{X}$ & $\mathrm{X}$ & $\mathrm{X}$ & $\mathrm{X}$ & $\mathrm{X}$ & $\mathrm{X}$ & $\mathrm{X}$ & $\mathrm{X}$ & $\mathrm{X}$ & $\mathrm{X}$ & $\mathrm{X}$ \\
\hline Origin Countries & 126 & 126 & 126 & 126 & 126 & 126 & 126 & 126 & 126 & 126 & 126 & 126 \\
\hline Dest. Countries & 113 & 113 & 25 & 25 & 6 & 6 & 19 & 19 & 25 & 25 & 25 & 25 \\
\hline Zeros & 12,572 & 12,572 & 2,746 & 2,746 & 321 & 321 & 1680 & 1680 & 2,003 & 2,003 & 4,046 & 4,046 \\
\hline
\end{tabular}

Notes: $t$ statistics are in parentheses; ${ }^{*} p<0.05,{ }^{* *} p<0.01,{ }^{* * *} p<0.001$. Standard Errors are clustered by country of origin.

Estimates are obtained using the Stata Command POI2HDFE to estimate Poisson PML gravity specifications using data from 2005-2015. The dependent variable is the number of inbound tertiary educated students. Column heading describes the sample. Figures reported in the Table are estimates of Equation (2). See Appendix Table 2 for the description of explanatory variables listed in column 1. 
Table 4: Estimated Association between Origin-Country Characteristics and International Student Mobility

(Poisson PML Model: Dependent Variable International Student Inbounds in,t ) Adding Institutional Variables

\begin{tabular}{|c|c|c|c|c|c|c|c|c|c|c|c|c|}
\hline Sample (Destinations) & $\begin{array}{c}1) \\
\text { Entire } \\
\text { Sample }\end{array}$ & $\begin{array}{c}(2) \\
\text { Entire } \\
\text { Sample }\end{array}$ & $\begin{array}{c}\text { (3) } \\
\text { Top } 25\end{array}$ & $\begin{array}{c}\text { (4) } \\
\text { Top 25 }\end{array}$ & $\begin{array}{c}\text { (5) } \\
\text { English } \\
\text { Speaking }\end{array}$ & $\begin{array}{c}6) \\
\text { English } \\
\text { Speaking }\end{array}$ & $\begin{array}{c}(7) \\
\text { OECD } \\
\text { Non- English }\end{array}$ & $\begin{array}{c}(8) \\
\text { OECD } \\
\text { Non- English }\end{array}$ & $\begin{array}{c}\text { (9) } \\
\text { Top 25 } \\
\text { OECD }\end{array}$ & $\begin{array}{c}(10) \\
\text { Top 25 } \\
\text { OECD }\end{array}$ & $\begin{array}{c}\text { (11) } \\
\text { Top 25 } \\
\text { Non-OECD }\end{array}$ & $\begin{array}{c}(12) \\
\text { Top 25 } \\
\text { Non-OECD }\end{array}$ \\
\hline Log Stock Emigrants in, t-5 & $\begin{array}{c}0.0496^{*} \\
(2.41)\end{array}$ & $\begin{array}{c}0.0470^{*} \\
(2.27)\end{array}$ & $\begin{array}{c}0.0681^{* *} \\
(2.71)\end{array}$ & $\begin{array}{c}0.0636^{*} \\
(2.52)\end{array}$ & $\begin{array}{l}0.133^{*} \\
(2.24)\end{array}$ & $\begin{array}{l}0.130^{*} \\
(2.14)\end{array}$ & $\begin{array}{c}0.0883^{*} \\
(1.99)\end{array}$ & $\begin{array}{l}0.0800 \\
(1.77)\end{array}$ & $\begin{array}{l}0.114^{* *} \\
(2.86)\end{array}$ & $\begin{array}{l}0.109^{* *} \\
(2.73)\end{array}$ & $\begin{array}{r}0.0163 \\
(0.87)\end{array}$ & $\begin{array}{l}0.0151 \\
(0.83)\end{array}$ \\
\hline Log Trade Total in,t-1 & $\begin{array}{c}0.00341 \\
(1.25)\end{array}$ & $\begin{array}{c}0.00309 \\
(1.17)\end{array}$ & $\begin{array}{c}0.00231 \\
(0.99)\end{array}$ & $\begin{array}{c}0.00164 \\
(0.77)\end{array}$ & $\begin{array}{c}0.00938 \\
(0.64)\end{array}$ & $\begin{array}{c}0.00526 \\
(0.39)\end{array}$ & $\begin{array}{r}-0.0261 \\
(-0.89)\end{array}$ & $\begin{array}{r}-0.0272 \\
(-0.94)\end{array}$ & $\begin{array}{c}0.00417 \\
(0.36)\end{array}$ & $\begin{array}{c}0.00231 \\
(0.21)\end{array}$ & $\begin{array}{c}0.00304 \\
(1.34)\end{array}$ & $\begin{array}{c}0.00300 \\
(1.28)\end{array}$ \\
\hline \multicolumn{13}{|l|}{ Origin characteristics: } \\
\hline Log GDP ppp pc $c_{n, t-1}$ & $\begin{array}{c}0.499^{* *} \\
(3.19)\end{array}$ & $\begin{array}{l}3.085^{*} \\
(2.39)\end{array}$ & $\begin{array}{c}0.576^{* * *} \\
(3.39)\end{array}$ & $\begin{array}{l}3.446^{*} \\
(2.54)\end{array}$ & $\begin{array}{c}0.789^{* * *} \\
(3.78)\end{array}$ & $\begin{array}{l}3.645^{*} \\
(2.02)\end{array}$ & $\begin{array}{l}0.142 \\
(0.91)\end{array}$ & $\begin{array}{l}1.912 \\
(1.29)\end{array}$ & $\begin{array}{l}0.538^{* *} \\
(3.02)\end{array}$ & $\begin{array}{l}2.470 \\
(1.58)\end{array}$ & $\begin{array}{l}-0.294 \\
(-1.14)\end{array}$ & $\begin{array}{l}4.380^{*} \\
(2.57)\end{array}$ \\
\hline$\left(\log \text { GDP ppp pc } c_{n, t-1}\right)^{2}$ & & $\begin{array}{l}-0.142^{*} \\
(-2.08)\end{array}$ & & $\begin{array}{l}-0.158^{*} \\
(-2.19)\end{array}$ & & $\begin{array}{l}-0.156 \\
(-1.65)\end{array}$ & & $\begin{array}{r}-0.0970 \\
(-1.19)\end{array}$ & & $\begin{array}{l}-0.106 \\
(-1.28)\end{array}$ & & $\begin{array}{l}-0.258^{* *} \\
(-2.69)\end{array}$ \\
\hline Log Population ${ }_{n, t-1}$ & $\begin{array}{l}0.240 \\
(1.06)\end{array}$ & $\begin{array}{l}0.232 \\
(1.01)\end{array}$ & $\begin{array}{l}0.304 \\
(1.22)\end{array}$ & $\begin{array}{l}0.305 \\
(1.22)\end{array}$ & $\begin{array}{l}0.271 \\
(1.02)\end{array}$ & $\begin{array}{l}0.296 \\
(1.10)\end{array}$ & $\begin{array}{c}0.0300 \\
(0.15)\end{array}$ & $\begin{array}{c}-0.00194 \\
(-0.01)\end{array}$ & $\begin{array}{l}0.171 \\
(0.71)\end{array}$ & $\begin{array}{l}0.174 \\
(0.71)\end{array}$ & $\begin{array}{l}0.508 \\
(1.86)\end{array}$ & $\begin{array}{l}0.426 \\
(1.63)\end{array}$ \\
\hline Share of Graduates. $n, t-1$ & $\begin{array}{l}-5.527 \\
(-0.68)\end{array}$ & $\begin{array}{l}-4.941 \\
(-0.64)\end{array}$ & $\begin{array}{l}-5.879 \\
(-0.60)\end{array}$ & $\begin{array}{l}-5.399 \\
(-0.58)\end{array}$ & $\begin{array}{l}5.698 \\
(0.46)\end{array}$ & $\begin{array}{l}4.285 \\
(0.39)\end{array}$ & $\begin{array}{l}-7.065 \\
(-0.67)\end{array}$ & $\begin{array}{l}-5.717 \\
(-0.55)\end{array}$ & $\begin{array}{l}-2.201 \\
(-0.21)\end{array}$ & $\begin{array}{l}-2.095 \\
(-0.20)\end{array}$ & $\begin{array}{c}-34.69^{* *} \\
(-3.20)\end{array}$ & $\begin{array}{l}-29.23^{* *} \\
(-2.76)\end{array}$ \\
\hline $\begin{array}{l}\text { Log Number of Univ. } \\
\text { Among Top } 500_{n, t-1}\end{array}$ & $\begin{array}{l}0.353^{*} \\
(2.27)\end{array}$ & $\begin{array}{l}0.384^{*} \\
(2.52)\end{array}$ & $\begin{array}{l}0.343^{*} \\
(2.10)\end{array}$ & $\begin{array}{l}0.376^{*} \\
(2.35)\end{array}$ & $\begin{array}{l}0.436^{*} \\
(2.24)\end{array}$ & $\begin{array}{l}0.472^{*} \\
(2.56)\end{array}$ & $\begin{array}{c}0.0620 \\
(0.45)\end{array}$ & $\begin{array}{c}0.0690 \\
(0.50)\end{array}$ & $\begin{array}{l}0.384^{*} \\
(2.19)\end{array}$ & $\begin{array}{l}0.406^{*} \\
(2.38)\end{array}$ & $\begin{array}{c}0.0931 \\
(1.10)\end{array}$ & $\begin{array}{l}0.152 \\
(1.70)\end{array}$ \\
\hline $\begin{array}{l}\text { Any Ranked University n,t-1 } \\
\text { (among the top 200) }\end{array}$ & $\begin{array}{r}0.0149 \\
(0.20)\end{array}$ & $\begin{array}{l}0.0301 \\
(0.42)\end{array}$ & $\begin{array}{l}0.0175 \\
(0.24)\end{array}$ & $\begin{array}{c}0.0337 \\
(0.48)\end{array}$ & $\begin{array}{c}0.0612 \\
(0.83)\end{array}$ & $\begin{array}{r}0.0710 \\
(0.97)\end{array}$ & $\begin{array}{r}-0.0695 \\
(-1.67)\end{array}$ & $\begin{array}{c}-0.0576 \\
(-1.37)\end{array}$ & $\begin{array}{c}0.0430 \\
(0.56)\end{array}$ & $\begin{array}{c}0.0533 \\
(0.71)\end{array}$ & $\begin{array}{l}-0.193^{*} \\
(-2.35)\end{array}$ & $\begin{array}{l}-0.161 \\
(-1.80)\end{array}$ \\
\hline Voice \& Accountability ${ }_{n, t-1}$ & $\begin{array}{l}-0.0423 \\
(-0.64)\end{array}$ & $\begin{array}{c}-0.0616 \\
(-0.91)\end{array}$ & $\begin{array}{c}-0.0279 \\
(-0.38)\end{array}$ & $\begin{array}{l}-0.0486 \\
(-0.63)\end{array}$ & $\begin{array}{l}-0.137 \\
(-0.79)\end{array}$ & $\begin{array}{l}-0.172 \\
(-1.01)\end{array}$ & $\begin{array}{c}0.0356 \\
(0.60)\end{array}$ & $\begin{array}{c}0.0299 \\
(0.51)\end{array}$ & $\begin{array}{l}-0.00462 \\
(-0.05)\end{array}$ & $\begin{array}{l}-0.0176 \\
(-0.20)\end{array}$ & $\begin{array}{r}-0.0747 \\
(-0.65)\end{array}$ & $\begin{array}{l}-0.130 \\
(-1.23)\end{array}$ \\
\hline Govt. Effectiveness ${ }_{n, t-1}$ & $\begin{array}{l}0.143 \\
(1.53)\end{array}$ & $\begin{array}{l}0.157 \\
(1.68)\end{array}$ & $\begin{array}{l}0.171 \\
(1.72)\end{array}$ & $\begin{array}{l}0.189 \\
(1.89)\end{array}$ & $\begin{array}{l}0.279^{*} \\
(2.12)\end{array}$ & $\begin{array}{l}0.305^{*} \\
(2.30)\end{array}$ & $\begin{array}{r}-0.0377 \\
(-0.42)\end{array}$ & $\begin{array}{r}-0.0330 \\
(-0.36)\end{array}$ & $\begin{array}{l}0.150 \\
(1.38)\end{array}$ & $\begin{array}{l}0.164 \\
(1.51)\end{array}$ & $\begin{array}{r}0.0355 \\
(0.30)\end{array}$ & $\begin{array}{r}0.0339 \\
(0.30)\end{array}$ \\
\hline Political Stability $\mathrm{n}, \mathrm{t}-1$ & $\begin{array}{c}-0.0266 \\
(-0.55)\end{array}$ & $\begin{array}{c}-0.0396 \\
(-0.93)\end{array}$ & $\begin{array}{l}-0.0176 \\
(-0.32)\end{array}$ & $\begin{array}{l}-0.0323 \\
(-0.66)\end{array}$ & $\begin{array}{r}0.0545 \\
(0.80)\end{array}$ & $\begin{array}{r}0.0342 \\
(0.53)\end{array}$ & $\begin{array}{l}0.100 \\
(1.62)\end{array}$ & $\begin{array}{c}0.0946 \\
(1.57)\end{array}$ & $\begin{array}{c}0.0479 \\
(0.86)\end{array}$ & $\begin{array}{l}0.0368 \\
(0.69)\end{array}$ & $\begin{array}{c}-0.150^{* * *} \\
(-3.37)\end{array}$ & $\begin{array}{c}-0.165^{* * *} \\
(-4.06)\end{array}$ \\
\hline$N$ & 57176 & 57176 & 24035 & 24035 & 6288 & 6288 & 16716 & 16716 & 23048 & 23048 & 17513 & 17513 \\
\hline Dest*Year FE & $\mathrm{X}$ & $\mathrm{X}$ & $\mathrm{X}$ & $\mathrm{X}$ & $\mathrm{X}$ & $\mathrm{X}$ & $\mathrm{X}$ & $\mathrm{X}$ & $\mathrm{X}$ & $\mathrm{X}$ & $\mathrm{X}$ & $\mathrm{X}$ \\
\hline Dest*Origin FE & $X$ & $\mathrm{X}$ & $X$ & $\mathrm{X}$ & $\mathrm{X}$ & $\mathrm{X}$ & $\mathrm{X}$ & $\mathrm{X}$ & $\mathrm{X}$ & $\mathrm{X}$ & $\mathrm{X}$ & $\mathrm{X}$ \\
\hline Origin Countries & 126 & 126 & 126 & 126 & 126 & 126 & 126 & 126 & 126 & 126 & 126 & 126 \\
\hline Dest. Countries & 113 & 113 & 25 & 25 & 6 & 6 & 19 & 19 & 25 & 25 & 25 & 25 \\
\hline Zeros & 12,564 & 12,564 & 2,744 & 2,744 & 319 & 319 & 1680 & 1680 & 2,000 & 2,000 & 4,044 & 4,044 \\
\hline
\end{tabular}


Table A1: Samples @ Destination

\begin{tabular}{|c|c|c|c|c|}
\hline Top 25 & English Speaking & OECD & OECD Non-English Speaking & Top 25 Non-OECD \\
\hline Australia & Australia & Australia & Austria & Belarus \\
\hline Austria & United Kingdom & Austria & Belgium & Brazil \\
\hline Belgium & United States & Belgium & Denmark & Bulgaria \\
\hline Canada & Canada & Canada & Finland & Cuba \\
\hline Czech Republic & New Zealand & Denmark & France & Cyprus \\
\hline France & Ireland & Finland & Germany & Czech Republic \\
\hline Germany & & France & Greece & Hong Kong \\
\hline Italy & & Germany & Iceland & Hungary \\
\hline Japan & & Greece & Italy & India \\
\hline Jordan & & Iceland & Japan & Jordan \\
\hline Korea (REP) & & Ireland & Luxembourg & Kazakhstan \\
\hline Netherlands & & Italy & Mexico & Korea (REP) \\
\hline New Zealand & & Japan & Netherlands & Kyrgyzstan \\
\hline Poland & & Luxembourg & Norway & Macau \\
\hline Russian Federation & & Mexico & Portugal & Malaysia \\
\hline Saudi Arabia & & Netherlands & Spain & Poland \\
\hline South Africa & & New Zealand & Sweden & Romania \\
\hline Spain & & Norway & Switzerland & Russian Federation \\
\hline Sweden & & Portugal & Turkey & Saudi Arabia \\
\hline Switzerland & & Spain & & Serbia and Montenegro \\
\hline Turkey & & Sweden & & Slovakia \\
\hline Ukraine & & Switzerland & & South Africa \\
\hline United Arab Emirates & & Turkey & & Thailand \\
\hline United Kingdom & & United Kingdom & & Ukraine \\
\hline United States & & United States & & United Arab Emirates \\
\hline
\end{tabular}

Notes: China is added in the Top 25, and Top 25 Non-OECD samples even though data are only available from 2011. The OECD sample is composed of countries that were part of the OECD group prior to 1995. More information can be found here: http://www.oecd.org/about/membersandpartners/list-oecd-member-countries.htm 
Table A2: Variables Used and Corresponding Sources

\begin{tabular}{|c|c|c|c|}
\hline Variable & Short description & & Source \\
\hline \multicolumn{4}{|l|}{$\underline{\text { Dependent variable }}$} \\
\hline $\begin{array}{l}\text { Student Flows } \\
\left(N_{i j t}\right)\end{array}$ & $\begin{array}{l}\text { Inbound Internationally Mobile } \\
\text { Country of Origin }\end{array}$ & Students by & $\begin{array}{l}\text { UIS UNESCO Institute for Statistics; } \\
\text { Center for Strategic and International } \\
\text { Studies, Washington DC; China Power } \\
\text { project. } \\
\text { https://chinapower.csis.org/data/inboun } \\
\text { d-international-students-china-2005- } \\
\underline{2016 /}\end{array}$ \\
\hline tory vari & & & \\
\hline
\end{tabular}

GDP Per Capita

(Log GDP ppp $p c_{n, t-1}$ )
GDP per capita, expressed in PPP constant US\$

(2011 prices)
The World Bank

$\begin{array}{ll}\text { Population } & \begin{array}{l}\text { Population of the age-group theoretically } \\ \text { corresponding to tertiary education as indicated by US UNESCO Institute for Statistics } \\ \text { theoretical entrance age and duration (number, both }\end{array} \\ \text { sexes) }\end{array}$

Colony

Dummy $=1$ if country pair ever in a colonial relationship, 0 otherwise (var: colony)

CEPII

$\begin{array}{ll}\begin{array}{l}\text { Stocks Emigrants } \\ (\text { Log Stock Emigrants } \text { in }, t-5)\end{array} & \begin{array}{l}\text { Stock of migrants born in country i and resident in } \\ \text { country } \mathrm{j} \text { in a given year } \mathrm{t} .\end{array} \\ \text { Comlang Ethno } & =1 \text { if common language is spoken by at least } 9 \% \text { of } \\ \text { population }\end{array}$

Distance $\quad$ Weighted Distance, pop-wt, km (var: distw) CEPII

Political Stability indicating more political stability.
Index ranging from -2.5 to 2.5 with higher value
World Development Indicators, the World Bank
Government Effectiveness Index ranging from -2.5 to 2.5 with higher value
indicating better government effectiveness.
World Development Indicators, the World Bank

\section{Voice and Accountability}

Trade Flows

(Log Trade Total $_{\text {in, },-1}$ )

\section{Share of Graduates}

Index ranging from -2.5 to 2.5 with higher value indicating better voice and accountability.
World Development Indicators, the World Bank
Aggregate Bilateral Trade in Current US dollars
BACI, CEPII

The share of graduates over total population in the country of origin

UIS UNESCO Institute for Statistics 


$\begin{array}{ll}\text { Number of Universities among } & \text { The number of universities ranked among the } \\ \text { the Top 500 } & \text { Top500 universities in the world by the Shanghai } \begin{array}{l}\text { Shanghai Ranking of World } \\ \text { Ranking }\end{array}\end{array}$

Any ranked University among the top 200
Dummy variable which takes the value of 1 if the country of origin has at least one university ranked in the Top 200, zero otherwise.
Shanghai Ranking of World

Universities 
Table A3 - Estimated Association between International Student Mobility and Origin-Country Characteristics (Less Parsimonious Gravity Model with Destination*Year and Origin*Year Fixed Effects but excluding Origin-Destination Effects) (Poisson PML Model: Dependent Variable International Student Flow in,t)

\begin{tabular}{|c|c|c|c|c|c|c|}
\hline Sample (Destinations) & $\begin{array}{c}(1) \\
\text { Entire } \\
\text { Sample }\end{array}$ & $\begin{array}{c}(2) \\
\text { Top } 25\end{array}$ & $\begin{array}{c}(3) \\
\text { English } \\
\text { Speaking }\end{array}$ & $\begin{array}{c}(4) \\
\text { Top } 25 \\
\text { Non-English }\end{array}$ & $\begin{array}{c}(5) \\
\text { Top 25 } \\
\text { OECD }\end{array}$ & $\begin{array}{c}6) \\
\text { Top 25 } \\
\text { Non-OECD }\end{array}$ \\
\hline Lagged Diaspora $_{\text {in, } t-5}$ & $\begin{array}{c}0.277^{* * *} \\
(15.71)\end{array}$ & $\begin{array}{c}0.297^{* * *} \\
(13.38)\end{array}$ & $\begin{array}{c}0.201^{* * * *} \\
(3.67)\end{array}$ & $\begin{array}{l}0.258^{* * * *} \\
(11.10)\end{array}$ & $\begin{array}{l}0.314^{* * * *} \\
(10.67)\end{array}$ & $\begin{array}{c}0.209^{* * * *} \\
(10.74)\end{array}$ \\
\hline Log Trade Total in,t-1 & $\begin{array}{c}0.0986^{* * *} \\
(3.42)\end{array}$ & $\begin{array}{l}0.165^{* *} \\
(3.00)\end{array}$ & $\begin{array}{l}0.0905 \\
(1.59)\end{array}$ & $\begin{array}{c}0.0604^{*} \\
(2.56)\end{array}$ & $\begin{array}{c}0.328^{* * * *} \\
(8.63)\end{array}$ & $\begin{array}{c}0.0354^{* *} \\
(2.69)\end{array}$ \\
\hline Colony in & $\begin{array}{c}0.348^{* * * *} \\
(3.29)\end{array}$ & $\begin{array}{l}0.313^{* *} \\
(2.77)\end{array}$ & $\begin{array}{l}0.130 \\
(0.67)\end{array}$ & $\begin{array}{c}0.351^{* *} \\
(3.01)\end{array}$ & $\begin{array}{c}0.336^{* *} \\
(2.75)\end{array}$ & $\begin{array}{l}0.158 \\
(0.79)\end{array}$ \\
\hline Comlang $_{\text {in }}$ & $\begin{array}{c}0.769^{* * * *} \\
(8.12)\end{array}$ & $\begin{array}{c}0.781^{* * * *} \\
(7.63)\end{array}$ & $\begin{array}{l}0.679 \\
(1.65)\end{array}$ & $\begin{array}{c}0.935^{* * *} \\
(9.30)\end{array}$ & $\begin{array}{c}0.809^{* * * *} \\
(8.45)\end{array}$ & $\begin{array}{l}0.440^{* *} \\
(3.28)\end{array}$ \\
\hline Log Distance $_{\text {in }}$ & $\begin{array}{c}-0.724^{* * *} \\
(-14.31)\end{array}$ & $\begin{array}{c}-0.591^{* * *} \\
(-8.73)\end{array}$ & $\begin{array}{c}-0.733^{* * *} \\
(-9.49)\end{array}$ & $\begin{array}{c}-0.918^{* * *} \\
(-14.14)\end{array}$ & $\begin{array}{c}-0.433^{* * *} \\
(-7.09)\end{array}$ & $\begin{array}{c}-1.046^{* * *} \\
(-16.39)\end{array}$ \\
\hline$N$ & 149557 & 64988 & 18047 & 59559 & 64241 & 44538 \\
\hline Dest $*$ Year Fixed Effect & $\mathrm{X}$ & $\mathrm{X}$ & $\mathrm{X}$ & $\mathrm{X}$ & $\mathrm{X}$ & $\mathrm{X}$ \\
\hline Origin*Year Fixed Effect & $\mathrm{X}$ & $\mathrm{X}$ & $\mathrm{X}$ & $\mathrm{X}$ & $\mathrm{X}$ & $\mathrm{X}$ \\
\hline
\end{tabular}

Table A4 - Estimated Association between International Student Mobility and Origin-Country Characteristics (Poisson PML Model: Dependent Variable International Student Flow in,t) Model with only positive Student Flows, no Zeros

\begin{tabular}{|c|c|c|c|c|c|c|}
\hline Sample (Destinations) & $\begin{array}{c}\text { (1) } \\
\text { Entire Sample }\end{array}$ & $\begin{array}{c}(2) \\
\text { Top } 25\end{array}$ & $\begin{array}{c}\text { (3) } \\
\text { English } \\
\text { Speaking }\end{array}$ & $\begin{array}{c}\text { (4) } \\
\text { Top } 25 \\
\text { Non-English }\end{array}$ & $\begin{array}{c}(5) \\
\text { Top } 25 \\
\text { OECD }\end{array}$ & $\begin{array}{c}(6) \\
\text { Top } 25 \\
\text { Non-OECD }\end{array}$ \\
\hline Lagged Diaspora $_{\text {in, } t-5}$ & $\begin{array}{c}0.0347^{* *} \\
(2.77)\end{array}$ & $\begin{array}{c}0.0557^{* * * *} \\
(3.65)\end{array}$ & $\begin{array}{c}0.0428 \\
(1.41)\end{array}$ & $\begin{array}{c}0.0489^{\text {**** }} \\
(3.55)\end{array}$ & $\begin{array}{c}0.0645^{* *} \\
(2.82)\end{array}$ & $\begin{array}{c}-0.0133 \\
(-1.16)\end{array}$ \\
\hline Log Trade Total in,t-1 & $\begin{array}{l}0.00945^{* * *} \\
\quad(3.50)\end{array}$ & $\begin{array}{c}0.00568^{*} \\
(2.15)\end{array}$ & $\begin{array}{r}0.0375^{*} \\
(2.07)\end{array}$ & $\begin{array}{c}0.00956^{* *} \\
(3.08)\end{array}$ & $\begin{array}{c}0.0341^{* *} \\
(2.90)\end{array}$ & $\begin{array}{c}0.00946^{* *} \\
(2.96)\end{array}$ \\
\hline$N$ & 105211 & 54230 & 16701 & 46914 & 54635 & 29572 \\
\hline Dest*Year FE & $\mathrm{X}$ & $\mathrm{X}$ & $\mathrm{X}$ & $\mathrm{X}$ & $\mathrm{X}$ & $\mathrm{X}$ \\
\hline Dest $*$ Origin FE & $\mathrm{X}$ & $\mathrm{X}$ & $\mathrm{X}$ & $\mathrm{X}$ & $\mathrm{X}$ & $\mathrm{X}$ \\
\hline Origin $^{*}$ Year FE & $X$ & $X$ & $\mathrm{X}$ & $\mathrm{X}$ & $\mathrm{X}$ & $\mathrm{X}$ \\
\hline
\end{tabular}




\section{References}

Abbott, A., Silles, M. (2015) Determinants of international student migration. World Economy, 39: 621-635.

Agasisti, T., Dal Bianco, A. (2007) Determinants of college student migration in Italy: empirical evidence from a gravity approach. Technical Report, Paper Presented at the Congress of the European Regional Science Association. Paris, September. Available at SSRN 1063481.

Alecke, B., Burgard, C., Mitze, T. (2013) The effect of tuition fees on student enrollment and location choice interregional migration, border effects and gender differences. Technical Report, Ruhr Economic Papers 404.

Aleksynska, Mariya, and Giovanni Peri. "Isolating the network effect of immigrants on trade." The World Economy 37.3 (2014): 434-455.

Becker, G. S. (1964) Human Capital: A Theoretical and Empirical Analysis, with Special Reference to Education. Chicago: University of Chicago Press.

Beine, M., \& Docquier, F. c. Ozden (2011):“Diasporas,”. Journal of Development Economics, 95(1), 30-41.

Beine, Michel, Romain Noël, and Lionel Ragot (2014). "Determinants of the international mobility of students." Economics of Education review 41: 40-54.

Beine, M., Delogu, M., Ragot, L. (2017) Understanding the Impact of Tuition Fees for Foreign Students: The Case of the UK. CREA Discussion Paper, 2017-07.

Beine, Michel, Marco Delogu, and Lionel Ragot (2018). "The role of fees in foreign education: Evidence from italy." Journal of Economic Geography.

Beine, Michel, and Christopher Parsons (2015). "Climatic factors as determinants of international migration." The Scandinavian Journal of Economics 117.2: 723-767.

Bessey, D. (2012) "International student migration to Germany." Empirical Economics 42.1: 345-361.

Bertoli, Simone, and Jesús Fernández-Huertas Moraga. "Multilateral resistance to migration." Journal of Development Economics 102 (2013): 79-100.

Bruckmeier, K., Fischer, G.-B., Wigger, B. U. (2013) Does Distance Matter? Tuition Fees and Enrollment of FirstYear Students at German Public Universities. Technical Report, CES IFO Working Paper 4258.

Clemens, M. A. (2014). Does development reduce migration? International Handbook on migration and Economic development, 152.

Dao, Thu Hien (2018), et al. "Migration and development: Dissecting the anatomy of the mobility transition." Journal of Development Economics 132: 88-101.

Dreher, Axel, and Panu Poutvaara. "Foreign students and migration to the United States." World Development 39.8 (2011): 1294-1307.

González, C. R., Mesanza, R. B., \& Mariel, P. (2011). The determinants of international student mobility flows: an empirical study on the Erasmus programme. Higher Education, 62(4), 413-430.

Gordon, Robert J. 2012. Is U.S. Economic Growth Over? Faltering Innovation Confronts the Six Headwinds, NBER Working Paper No. 18315 
Guimaraes Paulo and Pedro Portugal. "A Simple Feasible Alternative Procedure to Estimate Models with HighDimensional Fixed Effects", Stata Journal, 10(4), 628-649, 2010.

Harris, J. R., \& Todaro, M. P. (1970). Migration, unemployment and development: a two-sector analysis. The American economic review, 126-142.

Head, K., and T. Mayer (2014). Gravity Equations: Workhorse, Toolkit, and Cookbook. Handbook of International Economics, Volume 4, Chapter 4: 131-195.

Kahanec, M. and R. Králiková (2011), 'Pulls of International Student Mobility’, Discussion Paper No. 6233 (Bonn: IZA).

Larch, M., Wanner, J., Yotov, Y., \& Zylkin, T. (2017). The Currency Union Effect: A PPML Re-assessment with High) Dimensional Fixed Effects. Drexel University School of Economics Working Paper Series (2017). Drexel University.

Manpower Group, 2018. "Solving the Talent Shortage Build, Buy, Borrow and Bridge.”

Medrano, J. D. (2016). Globalization, transnational human capital, and employment in the European Union. International Journal of Comparative Sociology, 57(6), 449-470. https://doi.org/10.1177/0020715216684182

Ortega, F., and G. Peri (2013). The effect of income and immigration policies on international migration. Migration Studies 1(1): 47-74.

Perkins, R., Neumayer, E. (2014) Geographies of educational mobilities: exploring the uneven flows of international students. The Geographical Journal, 180: 246-259.

Rosenzweig, M. (2008). Higher education and international migration in Asia: Brain circulation. Annual World Bank conference on development economics (pp. 59-100).

Santos Silva, J., \& Tenreyro, S. (2006). The log of gavity. Review of Economics and Statistics, 88(4), 641-658.

Santos Silva, J., \& Tenreyro, S. (2011). Further simulation evidence on the performance of the Poisson pseudomaximum likelihood estimator. Economics Letters 112(2): 220-222.

Thomas, K. J., \& Inkpen, C. (2017). Foreign student emigration to the United States: Pathways of entry, demographic antecedents, and origin-country contexts. International Migration Review, 51(3), 789-820.

Todaro, M. P. (1969). A model of labor migration and urban unemployment in less developed countries. The American economic review, 59(1), 138-148.

UNESCO (2018) UIS.Stat. UNESCO Institute for Statistics (UIS). https://data.uis.unesco.org

Van Bouwel, L., \& Veugelers, R. (2013). The determinants of student mobility in Europe: the quality dimension. European Journal of Higher Education, 3(2), 172-190.

Van Mol C (2014) Erasmus student mobility as a gateway to the international labour market? In Gerhards J, Hans S and Carlson s (eds) Globalisierung, Bildung und grenzu"berschreitende Mobilita"t. Wiesbaden: Springer VS, pp. $295-314$.

Zong, Jie and Jeanne Batlava, 2018. International Students in the United States, Migration Policy Institute, Migration Information Source.

Wei, H. (2013). An empirical study on the determinants of international student mobility: a global perspective. Higher Education, 66(1), 105-122. 